\title{
Expression of a Rice Chitinase Gene Enhances Antifungal Response in Transgenic Litchi (cv. Bedana)
}

\author{
Dilip Kumar Das*, Amir Rahman \\ Post Graduate Department of Biotechnology, Tilka Manjhi Bhagalpur University, Bhagalpur, India \\ Email: *dilipdas1@live.com
}

How to cite this paper: Das, D.K. and Rahman, A. (2018) Expression of a Rice Chitinase Gene Enhances Antifungal Response in Transgenic Litchi (cv. Bedana). American Journal of Plant Sciences, 9, 2256-2275.

https://doi.org/10.4236/ajps.2018.911163

Received: August 25, 2018

Accepted: October 23, 2018

Published: October 26, 2018

Copyright $\odot 2018$ by authors and Scientific Research Publishing Inc. This work is licensed under the Creative Commons Attribution International License (CC BY 4.0).

http://creativecommons.org/licenses/by/4.0/

\begin{abstract}
To enhance the antifungal response of litchi, transferring rice chitinase gene under a maize-ubiquitin promoter along with its first intron into the zygotic embryos via Agrobacterium tumefaciens-mediated transformation generated transgenic plants. After co-cultivation for 2 days with recombinant Agrobacterium, zygotic embryos were transferred onto Murashige and Skoog (MS) medium consisted of MS salts and Gamborg (B5) vitamins with $2 \mathrm{mgl}^{-1} 2$, 4-dichlorophenoxyacetic acid (2, 4-D), $50 \mathrm{gl}^{-1}$ sucrose and $8 \mathrm{gl}^{-1}$ agar supplemented with $25 \mathrm{mgl}^{-1}$ hygromycin and $400 \mathrm{mgl}^{-1}$ cefotaxime. Embryos were selected passing through a series of MS modified media and the antibiotic resistant transgenic plantlets were analyzed. The integration and stability of the transgene was confirmed by PCR, RT-PCR, Southern blotting and by Western blot analyses. The transgenic plants exhibited higher chitinase activity than the non-transformed plants. The chitinase activity was also examined using the native polyacrylamide in-gel assay. These analyses indicated that the foreign gene was translated into the protein of expected molecular weight that showed chitinase activity. Following in-vitro inoculation of die-back, leaf spots and blight pathogen (Phomopsis sp.), the transgenic plants showed delayed onset of the disease and smaller lesions. The transgenic plants were adapted to the greenhouse and did not show any phenotypic alterations.
\end{abstract}

\section{Keywords}

Transgenic Litchi, Agrobacterium Tumefaciens, Blight, Die Back and Leaf Spots, Phomopsis sp., Somatic Embryogenesis, Transformation

\section{Introduction}

Litchi plants are cultivated commercially worldwide and India became second to 
China in lychee production, total plantings covering about 30,000 acres. There are also extensive plantings in Pakistan, Bangladesh, Burma, former Indochina, Taiwan, Japan, the Philippines, Queensland, Madagascar, Brazil and South Africa. It is economically important global fruit crop and is used in producing juice, wine, Jam, table litchi, dried fruit and fresh fruit. It contains Protein $(0.68-1.0 \mathrm{~g})$, Fat (0.3 - $0.58 \mathrm{~g})$, Carbohydrate (13.31 - $16.4 \mathrm{~g})$, Fiber (0.23 - $0.4 \mathrm{~g})$, Calcium $(8-10 \mathrm{mg})$ and organic compounds such as Thiamine $(28 \mathrm{mg})$, Nicotinic acid (0.4 mg), Riboflavin (0.05 mg) and Ascorbic acid (24-60 mg)/100 g of edible portion [1]. In India it is grown in three distinct agro-climatic zones i.e. sub-tropical, hot tropical and mild tropical climatic regions. Major litchi varieties produced in India are Purbi, Early and Late Bedana, Kashba, Shahi, China, Deshi, Dehra Rose, Longia etc. However, it is susceptible to an array of diseases. Fungal diseases, which cause extensive loss in yield and quality, have been the most serious problems for cultivation. The most important among them are die-back, leaf spots and leaf blight caused by Phomopsis sp. and only leaf blight by Gleosporium sp. respectively [2]. Indian litchi cultivars are mostly threatened by these two pathogens. In general, fungal infection decreases yield of fruits and their quality through a reduction in plant vitality and productivity or by direct infection of the fruit. Control is generally achieved by widespread application of fungicides. The economic costs and negative environmental impact associated with these applications have led to a recent search for alternative strategies, involving genetic manipulation of host defense mechanisms which offer a new perspective for introducing traits like disease resistance into the cultivars of Litchi chinensis.

Somatic embryogenesis and plantlet regeneration has been reported in litchi by culture of anthers [3], immature embryos [4] protoplasts from embryogenic suspensions obtained from immature zygotic embryo [5] which is an important, most favored, efficient transformation and regeneration tool for gene transfer into litchi. The first transformation experiments with leaf tissue of litchi ( L. chinensis Sonn.) expressed green fluorescent protein gene in transgenic calli, which failed to regenerate (Using an Agrobacterium-mediated transformation protocol, Puchooa 2004) [6]. Avocado transformation was reported by Litz \& Witjaksono (2002) [7], biotechnology of fruit and nut crops, biotechnology in Longan and litchi breeding [8], in-vitro regeneration and transformation of Litchi [8], somatic embryogenesis [9] and plant regeneration in tropical timber tree Spanish red cedar [10], in Schiscandra chinensis [11] and in Trifolium [12] and Agrobacterium-mediated transformation in Bixa. orellana L. [13], in Sesame [14], in Cotton [15], in Cocoa [16] and in Zoysia [17].

The gene transfer to litchi has been achieved till date by Agrobacterium-mediated transformation (Das et al., 1996, Puchooa, 2004) [6] [18]. Agrobacterium-mediated transformation has been most widely used and is compatible with both the production of cell suspension cultures and the regeneration of transgenic plants from a variety of litchi cultivars. 
It has been revealed that plants have defense systems, which involve pathogen-related proteins, e.g. chitinase [19] [20]. Pathogenesis-related (PR) protein encoding genes when over-expressed in crop plants have been shown to enhance resistance to many fungal diseases [21] [22]. There are many reports in which rice chitinase gene conferred resistance against herbicide bialaphos in bread wheat [23], resistance of rice against the Sheath Blight [24], and enhanced resistance to Rhizoctonia solani in rice [25] and enhanced resistance to Fusarium sp. in Pigeon pea [26] and wheat endochitinase gene in tomato and enhanced resistance to Fusarium aslyspermum [27]. Yamamoto et al. (2000) [28] also reported the rice chitinase gene $(R C C 2)$, classified as class I chitinase, expressed in grapevine for enhanced resistance to fungal pathogen.

In this paper, we report on the use of Agrobacterium method to overexpress another rice chitinase gene (RCC11) in L. chinensis cv. Bedana. The transgenic plants that exhibited higher chitinase activity than non-transgenic plants showed increased resistance to die-back, leaf spot and blight.

\section{Materials and Methods}

\subsection{Plant Material}

Immature litchi (L. chinensis Sonn.) fruits cv. Bedana were obtained from Horticulture Division, Bihar Agricultural College, Sabour, Bhagalpur, India after four weeks of anthesis, were washed in running tap water to free them from dust. Followed by these immature fruits were dipped into water mixed with 2 - 4 drops of tween 20 and remained there for $5 \mathrm{~min}$. After that these fruits were taken out and again dipped into $0.1 \% \mathrm{HgCl}_{2}$ and remained there for $10 \mathrm{~min}$. Followed by these processes fruits were rinsed thrice in sterile distilled water under aseptic conditions. These fruits' walls were incised and zygotic embryos were isolated. These zygotic embryos were the materials for transformation experiments.

\section{2. $R C C 11$ Chitinase Gene Cloned into pCAMBIA Vector}

In this study, the chitinase gene RCC11 from Oryza sativa X 54367, a nucleotide sequence of a rice genomic clone that encodes a class I endochitinase. Rice chitinase gene $(R C C 11)$ was cloned in pCAMBIA vector by Dr. S. Muthukrishnan, Kansas State University, USA.

\subsection{Transformation of Litchi}

Zygotic embryos of litchi ( $L$. chinensis Sonn. cv. Bedana) were transformed as described by Das et al. (2002) incised and infected with Agrobacterium tumefaciens strain LBA4404 harboring the binary vector pCAMBIA (CaMV-Ubi-RCC11), which contained the chitinase-coding region (GenBank Acc. No. X54367) solution for $30 \mathrm{~min}$. and remained in co-cultivation on MS basal medium in dark incubated at $28^{\circ} \mathrm{C}$. Following 2 days of co-cultivation in MS [29] basal medium, regeneration protocol (consists of different stages i.e. Zygotic em- 
bryos-calli-Protoplasts-somatic embryos-Plant) of Changhe Yu et al. (2000) [5] was followed and the zygotic embryos were sub-cultured in MS1 medium consisted of MS salts, B5 vitamin, $2 \mathrm{mgl}^{-1} 2,4-\mathrm{D}, 50 \mathrm{gl}^{-1}$ sucrose and $8 \mathrm{gl}^{-1}$ agar for 6 - 8 weeks maintained in darkness, incubated at $26^{\circ} \mathrm{C} \pm 11^{\circ} \mathrm{C}$ and were sub-cultured in 2 weeks' interval on fresh MS1 or MS2 (MS1 + STS $29.4 \mu \mathrm{M}$ ) medium. Embryogenic cultures, pale yellow and friable, appeared after $6-8$ weeks. All cultured media were supplemented with an appropriate concentration of antibiotics i.e. $25 \mathrm{mgl}^{-1}$ hygromycin and $400 \mathrm{mg} \mathrm{l}^{-1}$ cefotaxime. Subsequently, the calli were transferred to MS2 liquid medium for cell suspension culture and were sub-cultured weekly in fresh MS2 liquid medium and remained there in darkness for 2 - 9 months.

Followed by protoplasts were isolated from harvested cells of suspension cultures. For this cells were centrifuged and plasmolysed in CPW medium contains $\left(\mathrm{MgL}^{-1}\right) \mathrm{KH}_{2} \mathrm{PO}_{4}(27.2), \mathrm{KNO}_{3}(101), \mathrm{CaCl}_{2} \cdot 2 \mathrm{H}_{2} \mathrm{O}$ (1480), $\mathrm{MgSO}_{4} \cdot 7 \mathrm{H}_{2} \mathrm{O}$ (240), $\mathrm{KI}$ (0.16), $\mathrm{CuSO}_{4} \cdot 5 \mathrm{H}_{2} \mathrm{O}(0.025) \mathrm{pH} 5.8$ salts solution with $13 \%$ (w/v) mannitol for 1 h. The plasmolyticum was then removed and replaced by a filter-sterilized enzyme solution containing $0.8 \%(\mathrm{w} / \mathrm{v})$ Cellulase "Onazuka" RS, $0.4 \%(\mathrm{w} / \mathrm{v}) \mathrm{Ma}-$ cerozyme $\mathrm{R}-10,11 \%(\mathrm{w} / \mathrm{v})$ mannitol and $\mathrm{CPW}$ salts ( $\mathrm{pH}$ 5.8). The mixture was incubated on a rotary shaker $(45 \mathrm{rpm})$, in darkness, at $26^{\circ} \mathrm{C} \pm 1^{\circ} \mathrm{C}$ overnight. Digested cells were filtered through a $37 \mu \mathrm{m}$ nylon sieve and centrifuged $(100 \mathrm{~g}$, 5 min). Protoplasts were washed three times with CPW salts solution plus $11 \%$ $(\mathrm{w} / \mathrm{v})$ mannitol. These protoplasts were purified by sedimentation and washing method.

Protoplasts were washed in calcium-free CPW solution and re-suspended in an autoclaved solution consisting of $1.8 \%(\mathrm{w} / \mathrm{v})$ sodium alginate and $10 \%(\mathrm{w} / \mathrm{v})$ mannitol. Re-suspended protoplasts $\left(10^{5} \mathrm{ml}^{-1}\right)$ were embedded in Ca-alginate by dropping $1 \mathrm{ml}$ of the suspension from a borosilicate blood pipette into each Petri dish $(60 \times 15 \mathrm{~mm})$ containing $1 \%(\mathrm{w} / \mathrm{v}) \mathrm{CaCl}_{2} \cdot 2 \mathrm{H}_{2} \mathrm{O}$ and CPW salts. After $1 \mathrm{~h}$ at $26^{\circ} \mathrm{C} \pm 1{ }^{\circ} \mathrm{C}$, many Calcium alginate beads were formed which were washed in sterile distilled water. These beads were cultured on P11 liquid medium consisted of major salts of $\mathrm{KM} 8 \mathrm{P}$ medium $\left(\mathrm{NH}_{4} \mathrm{NO}_{3} 600, \mathrm{KNO}_{3} 1900, \mathrm{CaCl}_{2} \cdot 2 \mathrm{H}_{2} \mathrm{O}\right.$ $\left.600, \mathrm{MgSO}_{4} \cdot 7 \mathrm{H}_{2} \mathrm{O} 300, \mathrm{KH}_{2} \mathrm{PO}_{4} 170, \mathrm{KCl} 300 \mathrm{MgL}^{-1}\right)$, minor salts, iron and vitamins of MS basal medium $1 \mathrm{MgL}^{-1}$ 2,4-D, $0.2 \mathrm{mgl}^{-1} \mathrm{NAA}, 250 \mathrm{mgl}^{-1}$ glutamine, $0.5 \mathrm{mgl}^{-1}$ Zeatin, $200 \mathrm{MgL}^{-1}$ coconut water (the source of coconut water is unripe green coconut fruit), $0.45 \mathrm{M}$ glucose and $0.1 \mathrm{M}$ Sucrose in dark at $26^{\circ} \mathrm{C} \pm 1^{\circ} \mathrm{C}$. After 6 weeks Calcium alginate beads were cultured on liberating medium consisted of MS with $8 \%(\mathrm{w} / \mathrm{v})$ sucrose and $0.1 \mathrm{M}$ citric acid at $\mathrm{pH}$ 5.8. Cultures were incubated on a rotary shaker $(75 \mathrm{rpm})$ for $30 \mathrm{~min}$. Liberated protoplast-derived colonies were collected by centrifugation (100 g, $5 \mathrm{~min})$ and then transferred to B3MS medium consisted of MS salts and B5 vitamins with $1 \mathrm{mgl}^{-1}$ kinetin, $0.1 \mathrm{mgl}^{-1} \mathrm{NAA}, 500 \mathrm{mgl}^{-1}$ glutamine, $8 \%$ (w/v) sucrose, and $15 \mathrm{gl}^{-1}$ agar ( $\mathrm{pH}$ 6.2). Subculture was carried out at 2-week intervals. Somatic embryos ( $2 \mathrm{~mm}$ or longer) were transferred to a maturation medium B4MS consisted of 
MS salts and B5 vitamin with $500 \mathrm{mgl}^{-1}$ glutamine, $50 \mathrm{ml} \mathrm{l}^{-1}$ coconut water, $5 \%$ (w/v) sucrose, $9 \mathrm{gl}^{-1}$ agar ( $\mathrm{pH}$ 5.8). After 4 - 8 weeks on B4MS medium, somatic embryos were transferred and germinated on B5MS medium consisted of MS salts and $\mathrm{B} 5$ vitamins with $1 \mathrm{MgL}^{-1}$ kinetin, $5 \mathrm{mg} \mathrm{l}^{-1} \mathrm{GA}_{3}, 50 \mathrm{ml} \mathrm{l}^{-1}$ coconut water, $35(\mathrm{w} / \mathrm{v})$ sucrose, and $7 \mathrm{~g} \mathrm{l}^{-1}$ agar ( $\left.\mathrm{pH} 5.8\right)$ with a photoperiod of $16 \mathrm{~h}$ and light intensity $80 \mu \mathrm{mol} \mathrm{m} \mathrm{m}^{-2} \mathrm{~s}^{-1}$ ). Shoot elongation, proliferation, rooting and subsequent plantlet development were induced on half concentration of WPM medium consisted of $\left(\mathrm{gl}^{-1}\right)$ WPM salts mixture (2.3), Sucrose (30), $100 \times$ Vitamin stock $(1 \mathrm{ml}), 20 \times$ Fe-EDTA $(5 \mathrm{ml})$, myoinositol (0.1) supplemented with BAP $0.25 \mu \mathrm{M}+$ NAA $0.1 \mu \mathrm{M})$. Rooted plantlets were further acclimatized in vermiculite moistened with Hoagland [30] nutritive solution and finally transferred into garden soil and grown in green house.

Southern blot analysis. In order to confirm the transgene integration and to determine the number of copies of transgene ( $R C C 11)$ integrated, Southern blotting [31] experiments were performed. Genomic DNA (10 $\mu \mathrm{g})$ and plasmid as positive control were digested with PstI or SacII (New England Biolab); fragments were separated on $1 \%(\mathrm{w} / \mathrm{v})$ agarose gels at $25 \mathrm{~V}$ for $16 \mathrm{~h}$. The fractionated DNA was denatured with $0.5 \mathrm{M} \mathrm{NaOH}$ for $30 \mathrm{~min}$, neutralized with $25 \mathrm{mM}$ sodium phosphate buffer, $\mathrm{pH} 6.5$ and transferred onto positively-charged nylon membranes (Hybond N+, Amersham Biosciences, Hongkong). The transferred DNA was fixed to the membrane by baking at $80^{\circ} \mathrm{C}$ for $30 \mathrm{~min}$ followed by UV irradiation $\left(12 \times 10^{4} \mu \mathrm{J} \mathrm{cm}^{-2}\right)$ using a UV cross-linker (UV-Stratalinker 1800, USA). Blots were hybridized with $\left[\alpha^{-32} \mathrm{P}\right]$ dCTP-labelled PCR-derived $R C C 11$ or hpt genes as a probe using random primers labeling kit (New England Biolab) and detection were made by autoradiography carried out on Kodak Xomat x-ray film (Kodak) for 1d.

Reverse transcription-polymerase chain reaction $(R T-P C R)$ analysis. Total RNA was prepared from leaf tissues using Trizol Reagent as per the manufacturer's instructions (Trizol Reagent, Invitrogen life technologies, San Diego, California, USA). To detect the presence of rice chitinase mRNA transcripts in transformants, RT-PCR was carried out on $5 \mu \mathrm{L}$ of this RT product using $R C C 1$ lgene specific primers at $52^{\circ} \mathrm{C}\left(\mathrm{F}^{\prime}{ }^{\prime} \mathrm{TCTCCT}\right.$

TCAAGACGGCGTTCTGGTTC3'; R5'CTGGTTGTAGCAATCCAGGTTATC G-3') and cycle parameter was kept as mentioned in the section earlier to amplify 290-bp of rice chitinase. Untransformed plants cDNA was used as experimental control.

Biochemical analysis. The chitinase levels in transgenic litchi were determined using colorimetric enzyme assay, in-gel assay and western blot analysis. Total soluble proteins were extracted from frozen leaves (placed at $-80^{\circ} \mathrm{C}$ for a week) of the transformed and non-transformed samples. Leaves were homogenized with a pestle and mortar in liquid nitrogen and the frozen powder was suspended in 5 volumes of $0.1 \mathrm{M}$ sodium citrate buffer ( $\mathrm{pH}$ 6.0) containing 20 $\mathrm{mM}$ sodium ascorbate and polyclar AT. After two rounds of centrifugation at 
$13,000 \mathrm{rpm}$ for $15 \mathrm{~min}$ at $4^{\circ} \mathrm{C}$, the supernatants were recovered [28]. The protein concentrations in the extracts were estimated by the Bradford method [32]. Equal amount $(25 \mu \mathrm{g})$ of soluble proteins were loaded 1D SDS-gels and stained with $0.1 \%$ Coomassie brilliant blue R-250 (dissolved in 25\% methanol \& $10 \%$ acetic acid mixture for $20 \mathrm{~min}$ ) dye to ensure the equal loading of protein and de-stained in $10 \%$ acetic acid overnight and proceeded for western blotting by transferring proteins on to the nitrocellulose membrane and probed with anti-chitinase11 antibodies (Generously provided by Dr.M.V.Razam, Deptt. of Genetics, South Campus, University of Delhi, India) at 1:5000 dilution. The specific position of antigen-antibody complex on the membrane was visualized by using alkaline phosphatase linked to secondary antibodies and for in-gel assay-Chitinases isoforms were visualized by glycol chitin SDS-PAGE. The extract containing $70-100 \mu \mathrm{g}$ of soluble protein from different transgenic lines as well as the untransformed control were diluted 1:10 and subjected to SDS-PAGE with $5 \%$ stacking gels and $12 \%$ acrylamide resolving gels [33] incorporated with $0.01 \%$ glycol chitin as described by Trudel and Asselin [34]. Glycol chitin was prepared by acetylation of glycol chitosan, where $1 \mathrm{~g}$ of glycol chitosan (G-7753, Sigma, USA) was dissolved in $20 \mathrm{ml}$ of $10 \%$ acetic acid and the viscous solution was mixed and kept overnight at room temperature, and then $90 \mathrm{ml}$ methanol were added and mixed continuously. The solution was filtered through Whatman filter paper (No. 3) under vacuum. The resulting filtrate was mixed with 1.5 $\mathrm{ml}$ acetate anhydride. The formed gel was kept at room temperature for $30 \mathrm{~min}$, the excessive liquid was poured off, and the gel was cut into small slices and homogenized by homogenizer. The homogenate was centrifuged at room temperature at 30,000 rpm for $15 \mathrm{~min}$; the pellet was re-suspended in $100 \mathrm{ml}$ of double distilled water so that the final concentration of this stock is $1 \%$. After the electrophoresis, the gel was incubated with Triton X-100 solution, consisting of $0.1 \mathrm{M} \mathrm{NaOAc}\left(\mathrm{pH} \mathrm{5.0)}\right.$ ) and $1 \%$ Triton $\mathrm{X}-100$, at $37^{\circ} \mathrm{C}$ for $2 \mathrm{~h}$. The resultant gel was then stained with Coomassie Brilliant Blue R-250 for $1 \mathrm{~h}$ and de-stained with double distilled water for overnight. Gels were photographed with a Kodak digital camera and contrast was enhanced using Adobe Photoshop version (7.0) software.

Quantitative assay of Chitinase enzyme activity. A solubilized, ethylene glycol-chitin (Sigma-Aldrich) was used as a substrate for chitinase activity assay. The colorimetric analysis of chitinase enzyme activity of PCR, Southern and RT-PCR positive transgenic plants was done following the protocol of Stephan and Wolf (1990) with slight modifications in triplicate, where aliquots of $300 \mu \mathrm{l}$ of ethylene glycol-chitin (stock $2 \mathrm{mg} / \mathrm{ml}$ ) were mixed with $100 \mu \mathrm{l}$ of $200 \mathrm{mM}$ sodium acetate buffer, $\mathrm{pH} 5.0$ and $0.5 \mathrm{ml}$ enzyme solution, then incubated for $60 \mathrm{~min}$. at $37^{\circ} \mathrm{C}$ in circulating water bath. The reaction was terminated by the addition of $100 \mu \mathrm{HCl}(1.0 \mathrm{~N})$ on ice and incubated for $10 \mathrm{~min}$. to facilitate precipitation of the non-degraded substrate (chitin), was centrifuged at $14,000 \mathrm{~g}$ for 5 min. The resulting N-acetyl glucosamine (GlcNAc) residues were colorimetrically measured by the dinitrosalicylic acid (DNSA) method [35]). To $1 \mathrm{ml}$ of the 
reaction mixture, $1 \mathrm{ml}$ of DNSA was added and boiled for $10 \mathrm{~min}$. and then 0.4 $\mathrm{ml}$ of Potassium-Sodium tartarate was added. The mixture was cooled at room temperature and OD (optical density) was taken at $540 \mathrm{~nm}$. As appropriate controls enzyme and substrate blanks were included in the experiment. One unit was defined as the amount of enzyme that produced $1 \mu \mathrm{mol}$ of reducing sugars corresponding to $\mathrm{N}$-acetyl-D-glucosamine in $1 \mathrm{~min}$.

Pathogenicity test against die-back, leaf spots and blight. We evaluated the potential of tolerance of transgenic litchi transformed with $R C C 11$ to die-back, leaf spots and blight caused by Phomopsis sp. newly developing fifth or sixth matured fresh leaves in situ were punctured with needle and sprayed of thin film of spore solution of Phomopsis sp. for infection in moist condition (RH 80\%) and then detached after four to seven days and punctured again with needle for infection with spore solution from the in-vitro grown transgenic plants. Two leaves from each transgenic plant were placed adaxial side up onto $0.6 \%(\mathrm{w} / \mathrm{v})$ agar containing $40 \mathrm{mgl}^{-1}$ benzodiazoloe in a petri dish. As a control, leaves were taken from in-vitro grown non-transformed plants and were treated in same way as transgenic plant. $P . s p$. is an endophytic wound parasite and it can be cultured on Potato dextrose agar medium. The spores were collected either by washing die-back, leaf spots and blight infected leaves from Horticulture department, Bihar Agricultural College, Sabour, Bhagalpur in distilled water containing 0.01\% (v/v) Tween 20 or from $P . s p$. growing in culture medium. The spore suspension of Phomopsis sp. $(0.5 \mathrm{ml})$ with concentration (1.0 was sprayed on to each petri dish containing leaf and kept at saturated humidity at $25^{\circ} \mathrm{C}$. The degree of disease severity was scored using a visual assessment scale based on the size and characteristics of necrotic lesions. A 5-point disease rating scale based on the approximate percentage of leaf necrotic area after $15-28$ days of inoculation (1 $=0 \% ; 2=1 \%-20 \% ; 2=20 \%-30 \% ; 3=30 \%-40 \% ; 4=40 \%-50 \% ; 5=>50 \%$ ) (Yamamoto et al., 2000; Jayaraj and Punja, 2007) [28] [36] was employed. We also recorded the number of days required for the onset and complete chlorosis in each leaf in comparison to control. The diseased leaves of untransformed and non diseased leaves of transformed plants were digitally photographed. A separate portion of leaves of both non-transgenic and transgenic plants was electron micrographed.

Electron micrography. For surface ultra structure study under scanning electron microscope (SEM), small (1 - $8 \mathrm{~mm})$ leaves of both transgenic and non-transgenic litchi plants were punctured and infected in same manner as mentioned above as a specimen normally required being completely dry, since the specimen chamber was at high vacuum. Chemical fixation is required to preserve the specimen. Fixation of the litchi leaves was performed by incubation in a solution of a buffered chemical fixative, such as $2.5 \%$ glutaraldehyde in combination with $2 \%$ formaldehyde in $0.1 \mathrm{M}$ phosphate buffer at $\mathrm{pH} 7.2$ containing $0.03 \mathrm{M}$ sucrose for overnight at $4^{\circ} \mathrm{C}$ and it was subsequently washed in $0.1 \mathrm{M}$ phosphate buffered with $0.3 \mathrm{M}$ sucrose for $1 \mathrm{~h}$ for twice change. The sam- 
ples were then dehydrated in an acetone series (30\% - 100\%). After dehydration, critical point drying and coating with gold, the observation behavior of Phomopsis sp. was carried out with a SEM model-Leo 435 VP Leica, Cambridge (UK) at $20 \mathrm{KV}$. Each disease value was taken on averages of three experiments. In each experiment 6 detached leaves for disease value was taken in each petridish and three petridishes for each treatment and disease rating scale was based on the approximate percentage of leaf necrotic area after 15 - 28 days of inoculation. The percentage response of disease rating scale was different in different litchi plant's leaves i.e. 4.7 in non-transgenic and 4.6 to 1.3 in transgenic plants and full necrosis of leaves was observed in 69 days. The statistical significance on disease value was calculated by one-way ANOVA followed by Tukey's multiple comparison tests. All data analyses were performed using the Graph Pad software (Graph Pad in Stat. Software Inc. San Diego, CA 92130, USA).

\section{Results}

RCC11 chitinase gene cloned into $P C A M B I A$ vector. Class I chitinases are generally basic and contain a cysteine-rich $\mathrm{N}$-terminal domain with putative chitin-binding properties. They are usually localized to the vacuole and are potent inhibitors of many fungi, which have an open reading frame of $956 \mathrm{bp}$ and consist of 308 amino acids with an ATG start codon. A total of 70\% GC content with a molecular weight of the mature protein of $35 \mathrm{kDa}$ was used earlier to increase the degree of tolerance of grapevine against fungal (Uncinula necator) pathogen. It was observed that $R C C 11$ gene encodes chitinase enzyme which possibly dissolves chitinase wall of fungus for disease recovery and confers enhanced resistance to fungal pathogen Phomopsis sp. in litchi.

Transformation of litchi with the rice chitinase gene: Zygotic embryos were transformed by infecting incised embryos surface with the Agrobacterium tumefaciens strain LBA4404 containing the binary vector pCAMBIA1301-RCC11 (Figure 1). The proembryogenic callus, which was developed from zygotic embryos upon transfer from MS1 to MS2 semi-solid culture, forms friable embryogenic cultures composed of proembryogenic mass (PEMS) because STS helps in formation of friable callus by suppression of somatic embryo development (Figures 2(a)-(d)). These embryogenic calli when transferred to MS2 liquid medium formed a large number of PEMS round densely cytoplasmic cells in suspension in long duration i.e. 2 - 9 months (Figure 2(e)). It was observed that alternate liquid-solid subculture was critical for maintaining suspension culture of high quality otherwise in long duration of suspension culture, PEMS would not survive.

Protoplasts isolated from suspension cultures were highly cytoplasmic, uniform in size and contained many starch grains. The yield and viability of protoplasts was approximately $1 \times 10^{7}$ per $\mathrm{g}$ fresh weight and $92 \%$, respectively. Embedding of average density $15-20$ protoplasts $/ \mathrm{cm}^{3}$ in calcium alginate support cell division in $16 \mathrm{~h}$ after plating (but in control, without alginate, protop- 
lasts aggregate on $2^{\text {nd }}$ day and divided on plating) and direct formation of proembryos in calcium alginate beads (Figure 2(f)). P11 medium gave the best results, with $7 \%$ of protoplasts dividing normally once or twice. Two to four-celled proembryos or microcalli were observed in 4 days after protoplast culture initiation (Figures 2(g)-(i)). Microcalli and putatively transformed globular embryos were formed at a total combined frequency of $56 \%$ and were visible to the naked eye 6 weeks after plating. When the Ca-alginate beads were liquefied in citric acid buffer medium, all microcalli and globular embryos were come out. Released colonies were harvested and transferred onto B3MS medium (Figure 2(j)). In this medium somatic embryos were differentiated and developed from protoplast-derived cultures in 2, 4-D-free medium (Figure 2(k) and Figure 2(1)). After 4 weeks, somatic embryos (2 - $4 \mathrm{~mm}$ long) appeared in large numbers and most of them were white. To stimulate this further maturity, somatic embryos were transferred onto B4MS medium and incubated in darkness for another 4 or 8 weeks. Eight weeks culture was more favorable for shoot formation. Now these putatively transformed matured embryos were cultured on B5MS medium under $16 \mathrm{~h}$ photoperiod incubated at $26^{\circ} \mathrm{C} \pm 1^{\circ} \mathrm{C}$ (Figure $2(\mathrm{~m})$ ). These somatic embryos were germinated and formed both shoots and roots (Figure 2(n) and Figure 2(o)). The overall frequency of plantlet regeneration through the steps of embryo germination on the same medium was $20.9 \%$ (18 plantlets/86 embryos). Under these conditions we were able to block necrogenesis following of Agrobacterium co-cultivation. The stable transformed embryos were selected by periodic increase in hygromycin concentration. Initially after 20 days on medium containing $10 \mathrm{MgL}^{-1}$ hygromycin, a high number of germinated somatic embryos were obtained. When transferred to medium containing higher concentrations of the antibiotic $\left(15,20 \mathrm{MgL}^{-1}\right)$, many of the regenerants became yellowish, and were discarded after 50 days.

Of the germinating hygromycin resistant transgenic embryos, about $20 \%$ showed normal shoot and root development compared to a conversion frequency of $67 \%$ in the control plantlets. Nine regenerated lines (B-Chi-1, 2, 4, 5, 9, 10, 14, 15 and 18) were used for further analyses. Each transgenic line was derived from a single somatic embryo and grew on hygromycin-containing media. The putative transgenic plants had no phenotypic abnormalities in comparison to the untransformed control plants. The main hurdle for litchi explants i.e. zygotic embryos that just after incision a large amount of polyphenolics were secreted

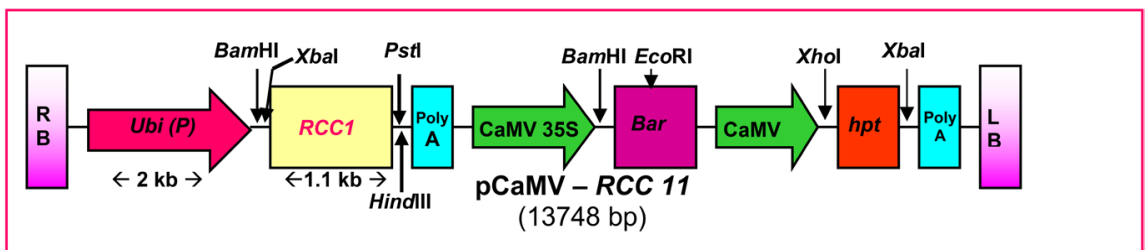

Figure 1. T-DNA plasmid map used for genetic transformation of litchi cv Bedana. The constitutive maize ubiquitin promoter drives expression of gene $R C C 11$ and the constitutive $35 \mathrm{~S}$ promoter drives the selectable marker hpt gene. 


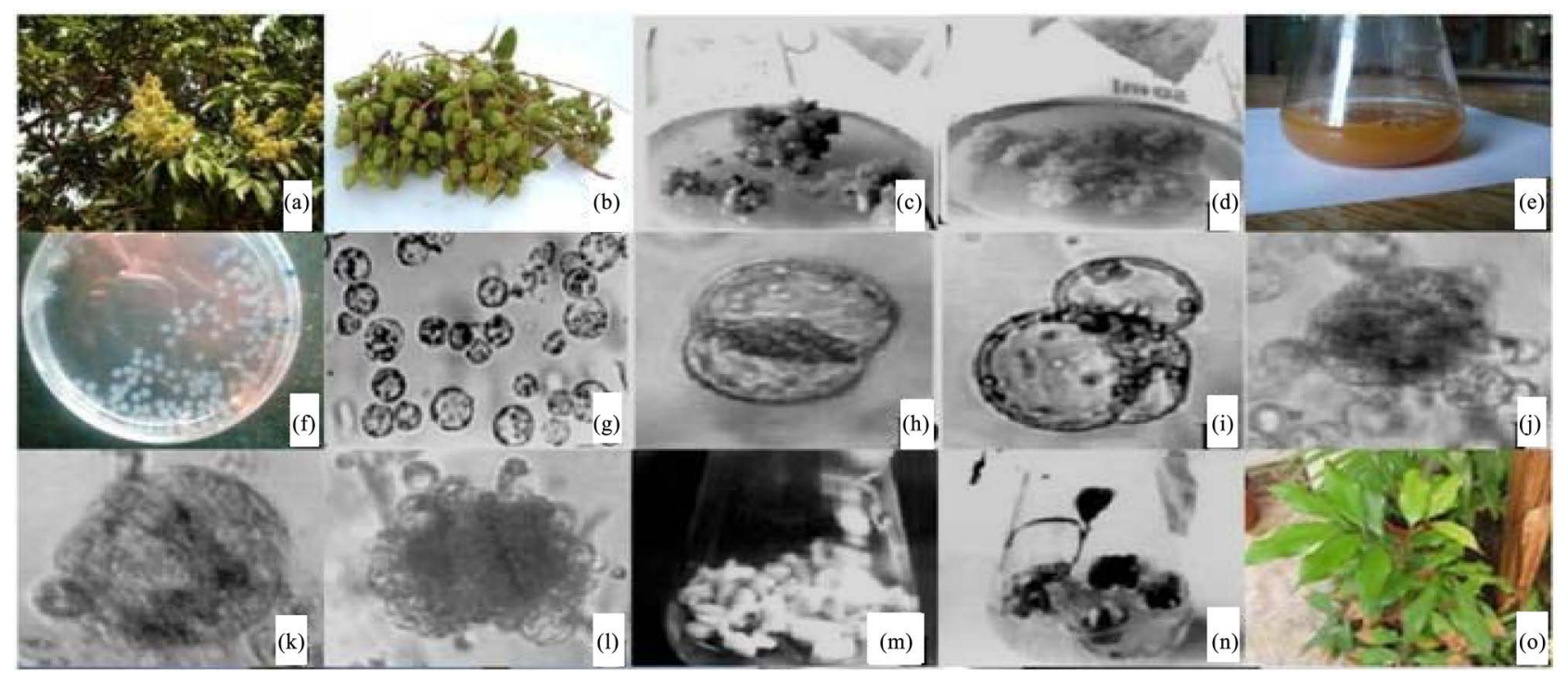

Figure 2. Production of transgenic litchi plants harboring the rice chitinase gene (RCC11) by the Agrobacterium tumefaciens infection method. (a) (b) Litchi panicle with large number of flowers and immature fruits; (c) (d) Embryogenic calli (friable) developed and selected on MS1 or MS2 media containing $20 \mathrm{mgl}^{-1}$ hygromycin after co-cultivation with $A$. tumefaciens; (e) Suspension cultures were grown in MS2 medium from 2 - 9 months; (f)-(n) Isolation of protoplast from suspension culture, formation of Calcium alginate beads and culture on P11 medium, liberation of embryogenic calli, development and maturation of putatively transformed somatic embryos and their germination into plantlets in liberation, B3MS, B4MS \& B5MS media; (o) Acclimatized plantlets in field soil.

which upon the action of polyphenoloxidase turned brown (due to melanin pigment) and cells were dead and unable to proliferate in-vitro condition. We controlled browning by the use of anti-oxidants (Ascorbic acid (AA) and citric acid (CA) which inhibited the action of polyphenol oxidase) and then incised zygotic embryos were cultured on MS 1 medium supplemented with AA + CA $\left(250 \mathrm{mgl}^{-1}\right)$ in the medium so that zygotic embryos formed proliferated calli under in-vitro conditions without showing necrosis.

Molecular and biochemical characterization of transgenic plants. The introgression of foreign genes and copy number pattern of integrated transgene in the nuclear genome of the PCR positive transgenic lines was confirmed by Southern hybridization. The genomic DNA $(5 \mu \mathrm{g})$ was digested with PstI restriction endonuclease enzyme in order to release the $R C C 11$ cDNA-terminator cassette $(\sim 1.1 \mathrm{~kb})$. The blot was probed with ${ }^{32} \mathrm{P}$-dCTP labeled $R C C 11 \mathrm{cDNA}$. In all the five transgenic lines analyzed, the expected $\sim 1.1 \mathrm{~kb}$ band lighted up at the position corresponding to the chitinase gene within their genome while it was absent in the untransformed control plant. Genomic DNA was also digested with SacII, which has single recognition site on the T-DNA region to determine the number of integration events and probed with ${ }^{32} \mathrm{P}$-dCTP labeled hpt gene fragment. Single bands were seen in all the transgenic lines confirming the single copy integration in all five lines (Figure 3 ).

We used RT-PCR analysis to check the expression of $R C C 11$ gene. In order to study the expression of mRNA for $R C C 11$ gene, total RNA was taken and RT-PCR analysis was performed from all five PCR positive lines using primers 
specific for the mRNA sequence of $R C C 11$. A 290-bp amplified fragment of mRNA corresponding to the $R C C 11$ transcript confirmed the expression of the rice chitinase gene. No amplification was observed in RNA samples isolated from un-transformed plant. RT-PCR results of all five independent transgenic lines (B-Chi 1, 4, 9, 15 and 18) are shown in Figure 4.

In-gel assay analysis showed number of chitinase isoforms from crude protein of transformed and untransformed plants separated by SDS-PAGE as shown in Figure 5. Untransformed protein extract displayed chitinase isoforms of molecular weights at 21 and $30 \mathrm{kDa}$. But an additional isoform of $35 \mathrm{kDa}$ was seen only in transformed lines.

Western blot analysis of representative lines employing polyclonal antibodies raised against rice chitinase 11 showed presence of a single prominent band corresponding to the size of $35 \mathrm{kDa}$ i.e. the expected size, indicating that the transgene is being expressed constitutively at a higher rate (Figure 6).

Higher chitinase activity was detected in all transgenic plants expressing the RCC11 gene investigated (chi4, chi9, chi15 and chi18) than in the non-transgenic plant. Lines 4 and 15 showed approximately two and three fold increase in the enzyme activity than non-transgenic plants, while lines 9 and 18 showed approximately one and half fold increase in the activity (Figure 6).

Evaluation of die-back, leaf spots and blight resistance in transgenic plants. Detached leaves of transgenic plants were tested for resistance to the phytopathogenic fungus, Phomopsis sp. Both Chi-4 and Chi-15 lines showed disease rating scores of 1.6 and 1.3 as an average score of three experiments, respectively, versus a score of 4.7 for the non-transformant (Table 1). These results indicate that the two transformants exhibited full resistance to Phomopsis sp., which was sufficient to delay the spread of lesion areas from the disease. The degree of disease symptoms correlated well with the level of chitinase enzyme accumulation. That is, the transgenic plants with a higher level of chitinase activity tended to have a smaller total lesion area. We also recorded the number of days required for the onset of necrosis. Since the leaves used for the experiment were similar in leaf position and size, we also recorded the number of days required for the complete necrosis in each leaf. The results are shown in Table 1. Similar to the result of disease index, both Chi-4 and Chi-15 lines took longer period than the control for the development of necrosis (Figures 7(a)-(c)). Electron micrograph studies showed that pathogenic fungal spores could easily germinate, ramify mycelium and also invade on leaf surface cells of non-transgenic litchi plants so that they developed die-back, leaf spots and blight disease in in-vitro grown plants but pathogenic spores were unable to germinate, ramify and invade the transgenic plants so that there was no development of disease (Figure $7(\mathrm{e})$ ).

\section{Discussion}

It has previously been reported that several plant species expressing the rice chitinase gene conferred an enhanced resistance to fungal disease, i.e., resistance of 
rice against the Sheath Blight [36] (Lin et al., 1995), transgenic indica rice variety Pusa Basmatil exhibits enhanced resistance to Rhizoctonia solani [25] and genetically transformed Pigeon pea for enhanced resistance to Fusarium sp. causing the wilt disease [26] and transgenic taro resistance against Sclerotium rolfsii [37]. Here, we present another illustration of enhanced resistance to die-back, leaf spots and blight in transgenic litchi. The present study shows that zygotic embryos derived embryogenic calli could be transformed by Agrobacterium-mediated transformation harboring the binary vector pCAMBIA-RCCI1.

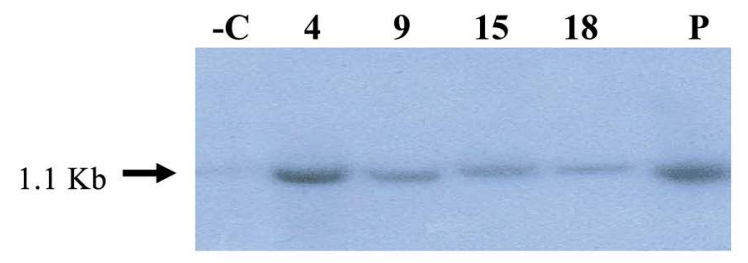

(a)

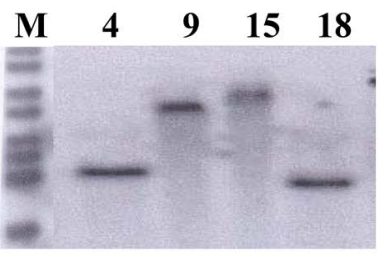

(b)

Figure 3. Southern Blot analysis of transgenic litchi cv Bedana. Genomic DNA (5 $\mu \mathrm{g})$ and plasmid digested with PstI (a) or SacII (b) were probed with PCR-generated fragments of chitinase $(R C C 11)$ and hpt gene. (Lanes -C: untransformed plant, P: plasmid-pCAMBIA- $R C C 11,4,9,15,18$ : different transgenic lines, $\mathrm{M}: 1 \mathrm{~Kb}$ marker).

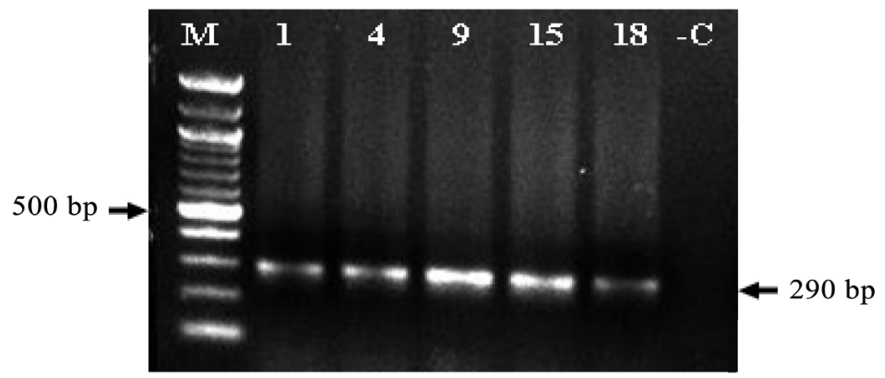

Figure 4. RT-PCR analysis of plant lines for transgenes (RCCl1gene). RT-PCR analysis of plant lines for transgenes. $400 \mathrm{ng}$ of total RNA was used for each reaction. Numbers indicate plant lines (1, 4, 9, 15 and 18); -C: untransformed plant negative control; M: 100 bp marker; Arrow indicates amplicon size: 290 bp internal sequence of rice chitinase (RCC11).

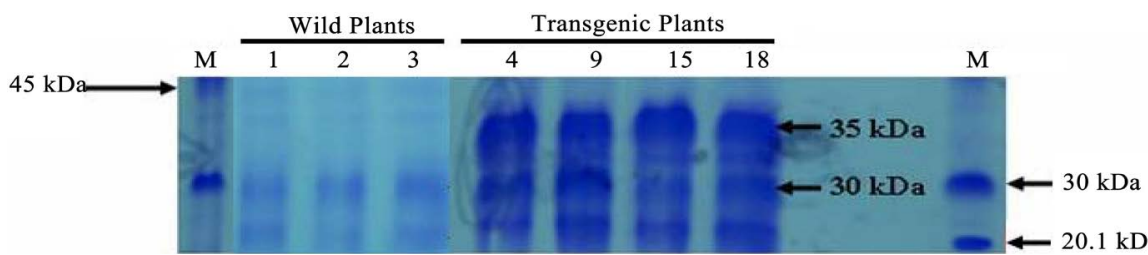

Figure 5. Biochemical analysis of transformed and untransformed litchi plants (cv Bedana). A and B: Detection of chitinolytic activity of chitinase after glycol chitin SDS-PAGE electrophoresis of untransformed and transformed litchi plants cv Bedana (Lanes 1, 2, 3 and 4 is untransformed plants showing two chitinase isoforms of 21 and $30 \mathrm{kDa}$ ). Lanes 4 , 9,15 , and 18 are individual transformed lines showing three isoforms of chitinsae i.e. 21 $\mathrm{kDa}$ and $30 \mathrm{kDa}$ like normal untransformed plants and $35 \mathrm{kDa}$ of unique size translated from rice chitinase $(R C C 11)$ gene. M-Rainbow marker was used as protein molecular weight standard. 


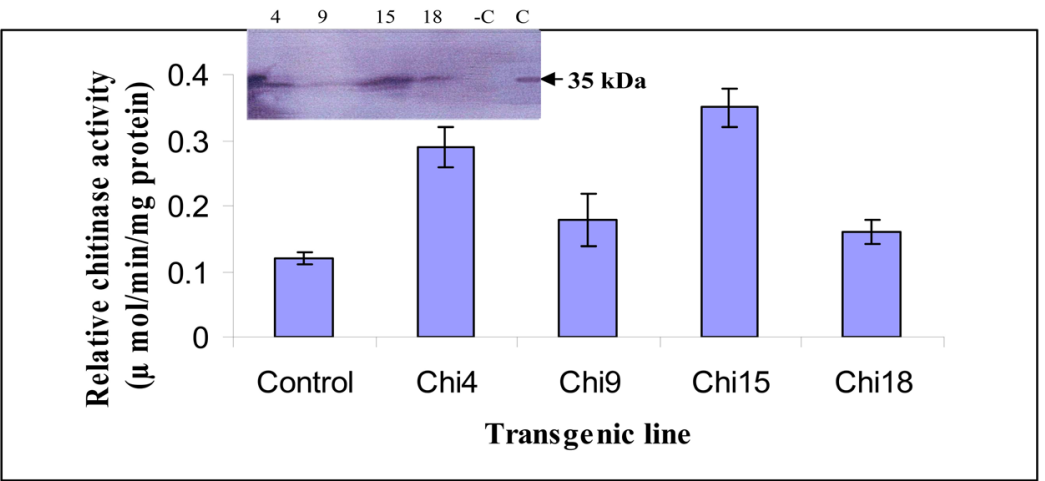

Figure 6. Chitinase enzyme assay of different transgenic lines of litchi cv. Bedana. Average values of three different experiments each in duplicates were plotted in the graphs. Inset shows Western blots analysis showing $35 \mathrm{kDa}$ bands.

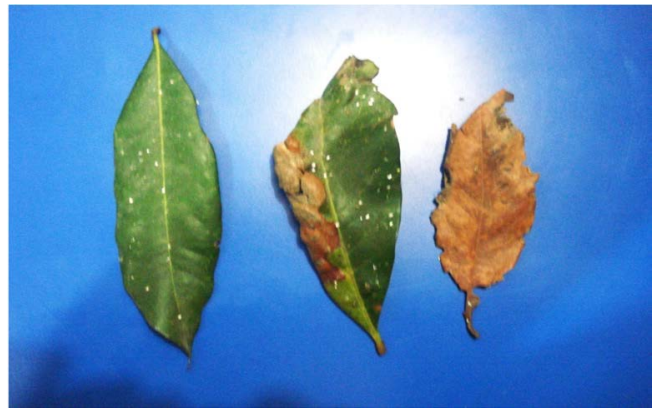

(a)

(b)

(c)

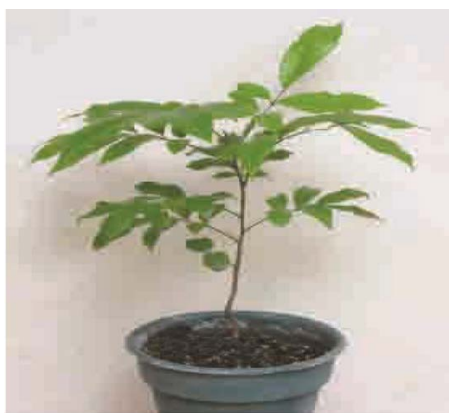

(d)

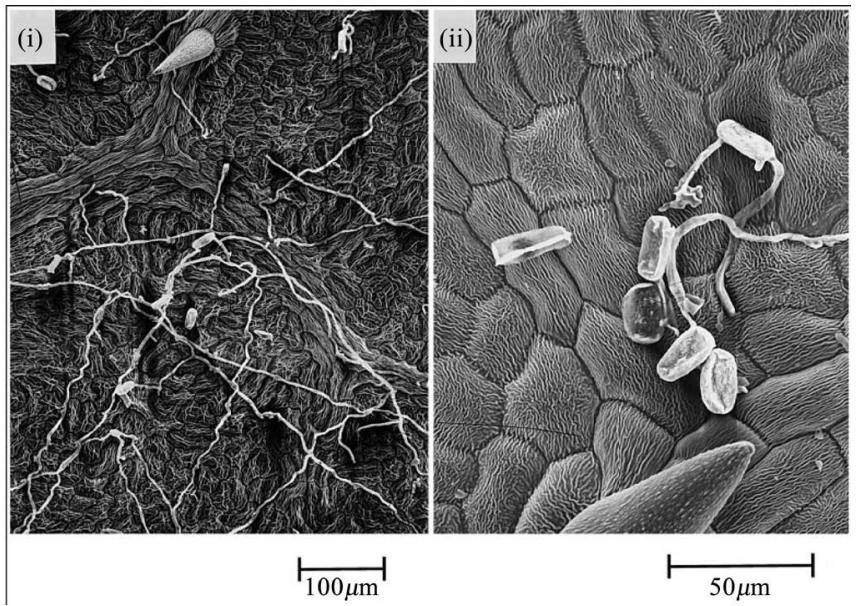

(e) 


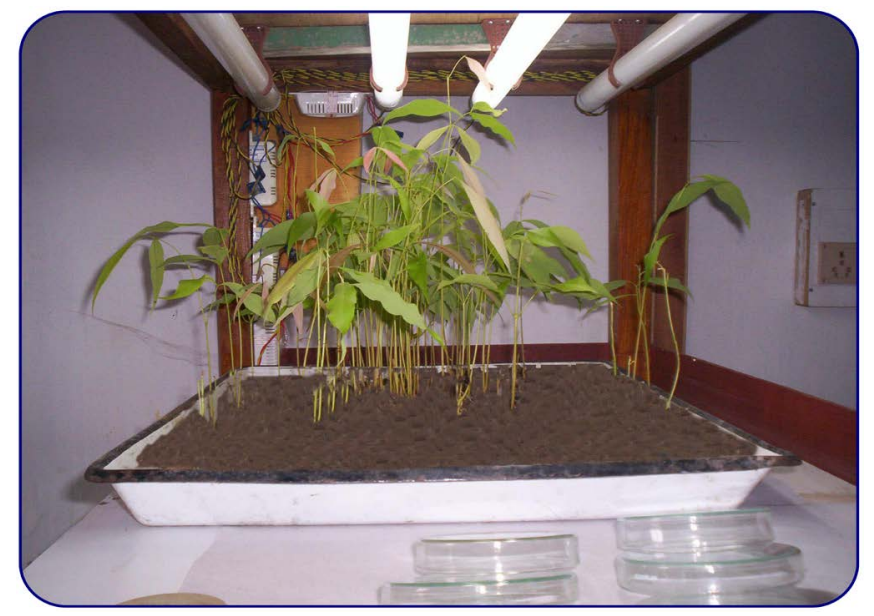

(f)

Figure 7. Study of growth of mycelium, development of diseases on detached leaves sprayed with thin film of spore's solution of Phomopsis sp. on in-vitro grown transformed and untransformed litchi plant and electron micrographs. (a) Detached leaf of transformed plant showed no development of mycelium and disease; (b) \& (c) Detached leaves of untransformed plant showed spore germination, growth of mycelium and development of disease; (d) Transgenic litchi plantlet in vermiculite; (e) Study of growth of mycelium on transformed and untransformed leaf under electron microscope; (i) Electron micrograph of untransformed litchi plant's leaf showing germination of fungal spores and growth of mycelium and entering inside leaf cells; (ii) Electron micrograph of transformed litchi plant's leaf showing very small germination of fungal spores and no growth of mycelium; (f) Transformed litchi plants in field soil.

Table 1. Tolerant potential of transgenic litchi plants to die-back leaf spots and blight and number of days required for onset of disease and the complete leaf necrosis on detached leaves from $R C C 11$ transgenic lines.

\begin{tabular}{cccc}
\hline No. of lines & $\begin{array}{c}\text { Disease rating scales for die-back } \\
\text { leaf spots and blight }\end{array}$ & First symptom (days) & $\begin{array}{c}\text { Fully covered } \\
\text { (days) }\end{array}$ \\
\hline B-Chi-1 & $4.6 \pm 0.52^{\mathrm{b}}$ & 6 & 19 \\
B-Chi-4 & $1.6 \pm 0.55$ & 39 & 64 \\
B-Chi-9 & $3.5 \pm 0.46$ & 6 & 18 \\
B-Chi-15 & $1.3 \pm 0.58$ & 45 & 69 \\
B-Chi-18 & $4.2 \pm 0.49$ & 7 & 20 \\
Non-transformed & $4.7 \pm 0.51$ & 3 & 14 \\
\hline
\end{tabular}

${ }^{\mathrm{a}} 0$, no symptoms; 5 , very severe symptoms, ${ }^{\mathrm{b}}$ mean $\mathrm{SD}( \pm)$ of disease rating scales.

These results demonstrated that zygotic embryos are well suited as target material for Agrobacterium tumefaciens-mediated transformation in litchi. The transformation process via Agrobacterium inoculation can cause necrosis; cell death of the tissue which could be reduced by special treatments [38]. Stress response may involve release of polyphenol from the vacuole [39] as well as de novo phenol synthesis [40] causing browning. We controlled browning of the tissue by the combined action of antioxidants i.e. Ascorbic and citric acids in the 
medium for in-vitro cell proliferation could be due to inhibitory effect on the polyphenol oxidase activity as reported earlier by Toth et al. 1993. Using the procedure of Changhe Yu et al. 2000 [5], the overall transformants frequency were $20.9 \%$ (18 plantlets/86 embryos) of hygromycin resistant plantlets regenerated through the steps of embryo germination, shoot formation and rooting could be achieved. It is known that genotype and developmental stage as well as endogenous growth regulators affects the response of explants to regeneration.

Molecular analyses involving PCR and southern blotting indicate the integration of T-DNA into the litchi genome. Four transformants (chi-4, 9, 15 and 18) were positive in Southern when probed with pCAMBIA-CaMV-Ubi-RCC11) gene sequences. Presence of a single band in the southern blotting experiments with DNA digested with SacII, probed with the hpt gene sequences suggests single copy integration events. The difference detected using the two different restriction enzymes could be ascribed according to the restriction sites, where PstI releases the $1.1 \mathrm{~kb}$ gene cassette while SacII would cut once in the T-DNA region. Different sized bands among the transgenic lines indicate independent transformation events. The presence of rice chitinase gene transcripts in transgenic plants was demonstrated by RT-PCR analysis. Densitometry assessment gave the integrated density value (IDV) of each band. This shows that line Chi-15 has a higher IDV than the rest. The higher level of transcript possibly results in more chitinase activity.

Expression of the $R C C 11$ by Western blotting clearly detected a specific signal for the rice chitinase in the transgenic plants. Transgenic line chi-15 showed an approximately two fold increase in the chitinase enzyme activity while the transgenic lines chi-4, 9 and 18 showed approximately one and half fold increase in the enzyme activity and this could be correlated well with the degree of resistance to the pathogens. Previous reports have also shown that elevated chitinase activity in transgenic strawberry [41], tobacco [42], rice [43], and cotton (Emani et al. 2003).

Delays in the development of symptoms of fungal disease were also observed in these transgenic plants expressing an exogenous chitinase gene [28] [42] [43]. We also observed that the symptoms of die-back, leaf spots and blight gradually progressed even on detached leaves of transgenic plants that exhibited high chitinase activity, so that the transgenic and non transgenic plants were indistinguishable when culture of the infected leaves was prolonged ( $>18$ days) as earlier reported by El-Eeeb et al. 2007, Kumaresan \& Suryanarayanan 2002 and Prompattha et al. 2010 [44] [45]. The previous reports and the present study indicate that high expression of the chitinase gene confers improved tolerance to die-back, leaf spots and blight disease on litchi plants, although the enhanced resistance is full and quantitative in transgenic line 15 . No somaclonal variation was observed in Chi 1, 4, 9, 15 \& 18 transformants. Since litchi is a tropical tree species, highly heterozygous and long generation period (10 - 15 years) so heritability study for at least two generations $\left(T_{1} \& T_{2}\right)$ is not possible because it will take long time (20 - 30 years). 
In the present study, we used the in-vitro inoculation method with detached leaves to evaluate the increased resistance against die-back, leaf spots and blight in transgenic plants (see Figures 7(a)-(d)). This method showed high accuracy for the detection of slight differences such as delay in the development of disease symptoms, in fully controlled conditions, between the original non-transgenic plant and primary transformants having the same genetic background.

\section{In Conclusion}

We demonstrate that the successful transformation of zygotic embryos derived somatic embryos of $L$. chinensis $\mathrm{cv}$. Bedana and regenerated into rooted plants. Following the successful integration of the transferred rice chitinase gene into the litchi genome, the expression of transferred gene and their activity, showed an increased resistance to leaf die-back by in vitro inoculation on detached leaves. Our next step will be focused on the evaluation and further improvement of the resistance against various fungal pathogens under greenhouse and field conditions. Together, these findings suggest that the rice chitinase RCC11 gene could be utilized as a genetic source of disease resistance for breeding and improve crop species. This is the first report of transgenic Litchi and uses the introduction of the chitinase gene as an example of the application of the technology.

\section{Acknowledgements}

Authors are grateful to the University Grants Commission, Govt. of India, New Delhi for providing financial assistance. We are highly thankful to Dr. M. V. Razam, Department of Genetics, South Campus, University of Delhi, New Delhi, India, for providing rice chitinase $11 \mathrm{cDNA}$ and antibody and Mr. S.C.B. Sharma, Advanced Instrumentation Research Facility, JNU, New Delhi for providing Electron micrography.

\section{Conflicts of Interest}

The authors declare no conflicts of interest regarding the publication of this paper.

\section{References}

[1] Morton, J.F. (1987) Fruits of Warm Climates. J.F. Morton, Miami, 249-259.

[2] Fu, L. and Tang, D. (1983) Introduction Pollen Plants of Litchi Tree (Litchi chinensis Sonn.). Acta Genetica Sinica, 10, 369-374.

[3] Zhou, L.N., Kuang, Z.S., Ma, X.J., Chen, J.Q., Tang, X.J. and Ling, X (1993) Preliminary Studies on Culture of Immature Embryos and Embryogenesis of Somatic Cells of Litchi (Litchi chinensis Sonn.). Guangdong Agricultural Sciences, 5, 14-15.

[4] Yu, C.H., Chen, Z.G., Lu, L.X. and Lin, J.W. (2000) Somatic Embryogenesis and Plant Regeneration from Litchi Protoplasts Isolated from Embryogenic Suspensions. Plant Cell, Tissue and Organ Culture, 61, 51-58.

https://doi.org/10.1023/A:1006446506041 
[5] Puchooa, D. (2004) Expression of Green Fluorescent Protein Gene in Litchi (Litchi chinensis Sonn.) Tissues. Journal of Applied Horticulture, 6, 11-15.

[6] Litz, R.E. and Witjaksono (2002) Avocado Transformation. In: Khachatourians, G., McHughern, A., Scorza, R., Nip, W.K. and Hui, Y.H., Eds., Transgenic Plants and Crops, Marcel Dekker, New York, 345-358.

[7] Zheng, Q.F., Hu, G.B. and Chen, D.C. (2001) Biotechnology in Longan and Litchi Breeding: Applications and Prospects. Acta Horticulturae, 558, 143-148. https://doi.org/10.17660/ActaHortic.2001.558.19

[8] Sarin, N.B. and Prasad, U.S. (2003) In Vitro Regeneration and Transformation of Litchi chinensis Sonn. In: Jaiwal, P.K. and Singh, R.P., Eds., Plant Genetic Engineering, Improvement of Major Vegetables and Fruit Crops, Vol. 6, SciTech Publishing, Houston, 211-222.

[9] Yuri, J.P.-R., Israel, G.-S., Angel, H.-E., Alfredo, D.-H., Felipe, A.B.-P., et al. (2011) Induction of Somatic Embryogenesis and Plant Regeneration in the Tropical Timber Tree Spanish Red Cedar [Cedrata oderata L. (Mediaceae)]. Plant Cell, Tissue and Organ Culture (PCTOC), 105, 203-209. https://doi.org/10.1007/s11240-010-9853-y

[10] Chen, A., Yang, J., Niu, Y.D., et al. (2010) High Frequency Somatic Embryogenesis from Germinated Zygotic Embryos of Schisandra chinensis and Evaluation of the Effects of Medium, Strength Sucrose, $\mathrm{GA}_{3}$ and BA in on Somatic Embryo Development. Plant Cell, Tissue and Organ Culture (PCTOC), 102, 357-364. https://doi.org/10.1007/s11240-010-9740-6

[11] Konieczny, R., Pilarska, M., Tuleja, M. and Salai, T. (2010) Somatic Embryogenesis and Plant Regeneration in Zygotic Embryos of Trifolium nigrescens (Viv). Plant Cell, Tissue and Organ Culture (PCTOC), 100, 123-130.

[12] Rangan, P., Akshatha, V., Parvatan, G. and Ravishankar, G.A. (2011) Somatic Embryogenesis and Agrobacterium-Mediated Transformation in Bixa orellana L. Plant Cell, Tissue and Organ Culture (PCTOC), 105, 317-328.

[13] Manju, Y., Darsana, C. and Manish S (2010) Agrobacterium tumefaciense-Mediated Transformation of Sesame (Sesamum indicum L.). Plant Cell, Tissue and Organ Culture (PCTOC), 103, 377-386. https://doi.org/10.1007/s11240-010-9791-8

[14] Tanveer, K., Vanga, R. and Leelavathi, S. (2010) High-Frequency Regeneration via Somatic Embryogenesis of an Elite Recalcitrant Cotton Genotype (Gossypium hirsutum L.) and Efficient Agrobacterium Mediated Transformation. Plant Cell, Tissue and Organ Culture (PCTOC), 101, 323-330. https://doi.org/10.1007/s11240-010-9691-y

[15] Costa, M.G.C., Silva, T.E.R., Cidade, L.C., Alvim, F.C., Cascardo, J.C.M. and Costa, M.G.C. (2009) Studies on Genetic Transformation of Theobroma cacao L.: Evaluation of Different Polyamines and Antibiotics on Somatic Embryogenesis and the Efficiency of UidA Gene Transfer by Agrobacterium tumefaciens. Plant Cell, Tissue and Organ Culture, 99, 281-298.

[16] Li, M., Li, H., Hu, X., Pan, X. and Niu, G. (2010) An Agrobacterium tumefaciens Mediated Transformation System Using Callus of Zoysia tenuifolia Willd ex Trin. Plant Cell, Tissue and Organ Culture, 102, 321-327. https://doi.org/10.1007/s11240-010-9736-2

[17] Das, D.K., Shiva Prakash, N. and Sarin, N.B. (1996) Regeneration and Transformation of Litchi (Litchi chinensis Sonn.). In Vitro Cellular \& Developmental Biology-Plant, 32, 63A.

[18] Legrand, M., Kauffmann, S., Geoffroy, P. and Fritig, B. (1987) Biological Function 
of Pathogenesis-Related Proteins: Four Tobacco Pathogenesis-Related Proteins Are Chitinases. Proceedings of the National Academy of Sciences of the United States, 84, 6750-6754. https://doi.org/10.1073/pnas.84.19.6750

[19] Nishizawa, Y. and Hibi, T. (1991) Rice Chitinase Gene: cDNA Cloning and StressInduced Expression. Plant Science, 76, 211-218. https://doi.org/10.1016/0168-9452(91)90143-V

[20] Jayraj, J., Anand, A. and Muthukrishnan, S. (2004) Pathogenesis-Related Proteins and Their Roles in Resistance to Fungal Pathogen. In: Punja, Z.K., Ed., Fungal Disease Resistance in Plants-Biochemistry, Molecular Biology and Genetic Engineering, Food Products Press (Haworth Press), New York, 139-178.

[21] Punja, Z.K. (2006) Recent Developments towards Achieving Fungal Disease Resistance in Transgenic Plants. Canadian Journal of Plant Pathology, 28, S298-S308. https://doi.org/10.1080/07060660609507387

[22] Chen, W.B., Xu, X., Liang, G.H., Muthukrishnan, S., Chen, P.D., Liu, D.J. and Gill, B.S. (1998) Introduction and Constitutive Expression of a Rice Chitinase Gene in Bread Wheat Using Biolistic Bombardment and bar Gene as a Selectable Marker. Theoretical and Applied Genetics, 97, 1296-1306. https://doi.org/10.1007/s001220051022

[23] Lin, W., Anuratha, C.S., Datta, K., Potrykus, I., Muthukrishnan, S. and Datta, S.K. (1995) Genetic Engineering of Rice for Resistance to Sheath Blight. Bio/ Technology 13, 685-691.

[24] Sridevi, G., Sabapathi, N., Meena, P., Nandakumar, R., Samiyappan, R., Muthukrishnan, S. and Veluthambi, K. (2003) Transgenic Indica Rice Variety Pusa Basmati 1 Constitutively Expressing a Rice Chitinase Gene Exhibits Enhanced Resistance to Rhizoctonia solani. Journal of Plant Biochemistry and Biotechnology, 12, 93-101. https://doi.org/10.1007/BF03263168

[25] Kumar, S.M., Kumar, B.K., Sharma, K.K. and Devi, P. (2004) Genetic Transformation of Pigeon Pea with Rice Chitinase Gene. Plant Breeding, 123, 485-489. https://doi.org/10.1111/j.1439-0523.2004.01028.x

[26] Girhepuje, P.V. and Shinde, G.B. (2011) Transgenic Tomato Plants Expressing a Wheat Endochitin Gene Demonstrate Enhanced Resistance to Fusarium oxysporum f. Sp. Lycopersici. Plant Cell, Tissue and Organ Culture, 105, 242-253. https://doi.org/10.1007/s11240-010-9859-5

[27] Yamamoto, T., Iketani, H., Ieki, H., Nishizawa, Y., Notsuka, K., Hibi, T., Hayashi, T. and Matsuta, N. (2000) Transgenic Grapevine Plants Expressing a Rice Chitinase with Enhanced Resistance to Fungal Pathogens. Plant Cell Reports, 19, 639-646. https://doi.org/10.1007/s002999900174

[28] Murashige, T. and Skoog, F. (1962) A Revised Medium for Rapid Growth and Bioassay with Tobacco Tissue Cultures. Physiology and Plants, 15, 472-497. https://doi.org/10.1111/j.1399-3054.1962.tb08052.x

[29] Hoagland, D.R. and Arnon, D.I. (1950) The Water-Culture Method of Growing Plants without Soil. California Agricultural Experiment Station, Bull. No. 347, Berkely.

[30] Southern, E.M. (1975) Detection of Specific Sequences among DNA Fragments Separated by Gel Electrophoresis. Journal of Molecular Biology, 98, 503-517. https://doi.org/10.1016/S0022-2836(75)80083-0

[31] Bradford, M.M. (1976) A Rapid and Sensitive Method for the Quantitation of Microgram Quantities of Protein Utilizing the Principle of Protein-Dye Binding. Analytical Biochemistry, 72, 248-254. https://doi.org/10.1016/0003-2697(76)90527-3 
[32] Laemmli, U.K. (1970) Cleavage of Structural Proteins during the Assembly of the Head of Bacteriophage T4. Nature, 227, 680-685. https://doi.org/10.1038/227680a0

[33] Trudel, J. and Asselin, A. (1989) Detection of Chitinase Activity after Polyacrylamide Gel Electrophoresis. Analytical Biochemistry, 178, 362-366.

https://doi.org/10.1016/0003-2697(89)90653-2

[34] Miller, G.L. (1959) Use of Dinitrosalicylic Acid Reagent for the Determination of Reducing Sugar. Analytical Chemistry, 31, 426-428. https://doi.org/10.1021/ac60147a030

[35] Jayaraj, J. and Punja, Z.K. (2007) Combined Expression of Chitinase and Lipid Transfer Protein Genes in Transgenic Carrot Plants Enhances Resistance to Foliar Fungal Pathogens. Plant Cell Reports, 26, 1539-1546.

https://doi.org/10.1007/s00299-007-0368-x

[36] He, X., Miyasaka, S.C., Fitch, M.M., Moore, P.H. and Zhu, Y.J. (2008) Agrobacterium Mediated-Transformation of Taro (Colocasia esculenta (L.) Schott) with a Rice Chitinase Gene for Improved Tolerance to a Fungal Pathogen Sclerotium rolfsii. Plant Cell Reports, 27, 903-909. https://doi.org/10.1007/s00299-008-0519-8

[37] Perl, A., Lotan, O., Abu-abied, M. and Holland, D. (1996) Establishment of an Agrobacterium-Mediated Transformation System for Grape (Vitis vinifera L.): The Role of Antioxidants during Grape-Agrobacterium Interactions. Nature Biotechnology, 14, 624-628. https://doi.org/10.1038/nbt0596-624

[38] Lagrimi, L.M. (1992) Wound-Induced Deposition of Polyphenols in Transgenic Plants over Expressing Peroxidase. Plant Physiology, 96, 577-583.

https://doi.org/10.1104/pp.96.2.577

[39] Hahlbrock, K. and Scheel, D. (1989) Physiology and Molecular Biology of Phenylpropanoid Metabolism. Annual Review of Plant Physiology and Plant Molecular Biology, 40, 347-369. https://doi.org/10.1146/annurev.pp.40.060189.002023

[40] Asao, H., Nishizawa, Y., Arai, S., Sato, T., Hirai, M., Yoshida, K., Shinmyo, A. and Hibi, T. (1997) Enhanced Resistance against a Fungal Pathogen Sphaerotheca humuli in Transgenic Strawberry Expressing a Rice Chitinase Gene. Plant Biotechnology, 14, 145-149. https://doi.org/10.5511/plantbiotechnology.14.145

[41] Broglie, K., Chet, I., Holliday, M., Cressman, R., Biddle, P., Knowlton, S., Mauvais, C.J. and Broglie, R. (1991) Transgenic Plants with Enhanced Resistance to the Fungal Pathogen Rhizoctonia solani. Science, 254, 1194-1197. https://doi.org/10.1126/science.254.5035.1194

[42] Nishizawa, Y., Nishio, Z., Nakazono, K., Soma, M., Nakajima, E., Ugaki, M. and Hibi, T. (1999) Enhanced Resistance to Blast (Magnaporthe grisea) in Transgenic Japonica Rice by Constitutive Expression of Rice Chitinase. Theoretical and Applied Genetics, 99, 383-390. https://doi.org/10.1007/s001220051248

[43] El-Deeb, H.M., Lashin, S.M. and Arab, Y.A. (2007) Distribution and Pathogenesis of Date Palm Fungi in Egypt. Acta Horticulturae, 736, 421-429. https://doi.org/10.17660/ActaHortic.2007.736.39

[44] Kumaresan, V. and Suryanarayanan, T.S. (2002) Endophyte Assemblages in Young, Mature and Senescent Leaves of Rhizophora apiculata: Evidence for the Role of Endophytes in Mangrove Litter Degradation. Fungal Diversity, 81-91.

[45] Promputtha, I., Hyde, K.D., McKenzie, E.H.C., Peberdy, J.F. and Lumyong, S. (2010) Can Leaf Degrading Enzymes Provide Evidences That Endophytic Fungi Becoming Saprobes? Fungal Diversity, 41, 89-99.

https://doi.org/10.1007/s13225-010-0024-6 


\section{Abbreviations}

B5-Gamborg et al. (1968): CPW salts. Frearson et al. (1973): 2, 4-D-2, 4-dichlorophenoxyacetic acid: $\mathrm{GA}_{3}$-gibberellic acid: HPT-hygromycin phospotransferase gene: IBA-indole3-butyric acid: MS-Murashige and Skoog (1962): NAA- $\alpha$-naphthalene acetic: $8 \mathrm{P}-\mathrm{Kao}$ and Michayluk (1975): STS-silver thiosulphate: SDS-PAGE-sodium dodecylsulphate polyacrylamide gel electrophoresis: WPM-Lloyd and McCown (1980). 